line up Borrowdale, between Keswick and Resthwaite, including a loop-line along the far side of Derwentwater, without extra charge to individual consumers in the valley. This result is attributed to the intervention of the Minister of Fuel and Power, following the representations made by the National Parks Commission to that Minister and to the Minister of Housing and Local Government. Negotiations in regard to Langdale and in regard to Patterdale continue. The society, with the Council for the Preservation of Rural England, has also reached a satisfactory agreement with the Forestry Commission in regard to any land within the 300 square miles of the central Lake District which the Commission might acquire and which was not under woodland in 1936. The National Trust has also agreed in replanting its woodlands at Loweswater and above Buttermere to bring in a firm policy of introducing or carefully re-generating hardwoods wherever the ground is not too wet.

\section{Brazilian Association for the Progress of Science}

This year's meeting of the Brazilian Association for the Progress of Science will be held at Ouro Preto (Minas Gerais) during July 2-7, and as planned at present there will be eighteen sections, although this number is likely to be reduced later. The main themes for the meeting will include "Problems of the Atomic Age" (Physics Section), "The Problem of Petroleum in Brazil" (Geology Section) and "University Teaching of Science" (Education Section). Other topics of special interest are "The Use of Isotopes in Technology", "Ionospheric Exploration", "Metallurgy of Pudio-active Metals", "Animal Movement" and, possibly, "Raurolfia serpentina". Tho groat natural resources of Minas Gerais State and the existence of a mining school in Ouro Preto give a specially geological regional interest to the meeting, which will be brought out in various papers to be read on mining for iron and gold, on petroleum and on minoralogy and geology generally. Among the British contributions to the meeting will be a showing arranged by the British Council of a number of recent scientific films, and an address on "The Teaching of Science and Technology in British Universities" by Mr. F. M. Beatty, the British (Youncil's science officer in Brazil.

\section{Oil and Colour Chemists' Association: Eighth Technical Exhibition}

THE eighth technical exhibition of the Oil and Colour Chemists' Association, organized by the London Section of the Association, will be held during March 20-22 in the Royal Horticultural Society's New Hall, Grey Coat and Elverton Streets, London, S.W.1, at the following times: March 20, 3 p.m. -8.30 p.m. ; and March 21 and 22, 11 a.m.7.30 p.m. As before, the theme of the exhibition will be the presentation of technical advances in those industries supplying tho paint, varnish, printing ink, linoleum and other allied industries. The area covered by the exhibition and the total number of companies and research associations exhibiting (eighty-two in all) are the largest yet reached. A ninety-two page catalogue of the exhibition has been prepared and is available. Admission to the exhibition is froe. Further information can be obtained from the general secretary, R. H. Hamblin, Oil and Colour Chemists' Association, Memorial Hall, Farringdon Street, London, E.C.4.

\section{Optics Meetings in the United States}

THe International Commission for Optics will meet this year in the Massachusetts Institute of Technology, Cambridge, Mass., during March 28-April 3, and will devote four days to a symposium on "Frontiors in Physical Optics", which will be open to all interested. At the symposium the follow. ing topics will be diseussed : new phase-contrast and interference microscopic and measuring devices; thin films and filters; meteorological optics; and nuclear optics. The main papers for these sessions have already been invited and prepared, but time will be reserved for free discussion. In addition to these events, the regular spring meeting of the Optical Society of America will be held during April 5-7 in Philadelphia, Pennsylvania, and this also will be open to all interested. Further information about the meetings can be obtained from Dr. S. S. Ballard, Visibility Laboratory, Scripps Institution of Oceanography, University of California, San Diego 52, Calif.

\section{Announcements}

RAymund L. Zwemer, formerly chief of the Science Division of the Library of Congress, has been appointed head of the Division of International Cooperation for Scientific Research in the Natural Science Department of the United Nations Educa. tional, Scientific and Gultural Organization. He will be responsible for Unesco's relations with international scientific unions and other organizations concerned with scientific research on an international scale.

Sir Eric Rideal is to deliver a course of three lectures on "Colloids and their Behaviour" at the Royal Institution on February 28, March 6 and 13 at 6 p.m. This is a refresher course intended primarily for school teachers. Members of the London Branches of the Science Masters' Association and the Association of Women Science Teachers will be notified by their Associations about applications for tickets; non-members should apply to a local branch secretary of one of the Associations.

THe Institution of Naval Architects is offering two scholarships in naval architecture-the I.N.A.-ElgarMartell of $£ 275$ a year, and the Vickers-Armstrongs of $£ 220$ a year--both of which are tenable for three or four years at a university institution. They are open to British subjects, less than twenty-three years old, who have been employed in shipbuilding. Applications should be made by May 31 to the Secretary of the Institution at 10 Upper Belgrave Street, London, S.W.1.

THE Council of Europe and the High Authority of the European Coal and Steel Community will award jointly a number of fellowships this year for research into problems of European interest. The fellowships will be worth 300,000 francs each (about $£ 300$ ). The fields of work applicable are as follows: efforts to achieve European integration by co-ordination in the political, social, economic, scientific or educatioral fields; European civilization in relation to contemporary problems (philosophy, history, literature or the arts); economic, legal or social problems relating to the European Coal and Steel Community and its institutions. Candidates from Great Britain should obtain their application forms from the Education Division, British Council, 65 Davies Street, London, W.1, and return them before March 15. 